\title{
Bacterial causes of decrease in performance of the breeder chicken flocks
}

\author{
M. M. Amer ${ }^{*}$, Wafaa A. Abd El-Ghany \\ Department of Poultry Diseases, Faculty of Veterinary Medicine, Cairo University, Egypt.
}

\begin{abstract}
This study was carried out to investigate the possible bacterial causes affecting the productivity of the breeder hens. The hens under test were positive for Mycoplasma gallisepticum (MG) and Mycoplasma synoviae (MS) and negative for Salmonella gallinarum-pullorum (S. $g-p)$ as tested by serum agglutination test. Ovaries with lesions were bacteriologically and serologically proven to have 12 bacterial isolates including three un-typed $E$. coli, one O11, and one O78; three Staphylococcus aureus; one S.g-p; two Proteus and one Pseudomonas aeruginosa (P. aeruginosa) isolates. The antibiogram of the two identified $E$. coli strains, $S$. $g$ - $p$ as well as $P$. aeruginosa showed variable sensitivity. The tested organisms were very sensitive to colistin and enrofloxacin. The selected $E$. coli, S.g-p and $P$. aeruginosa strains proved to be pathogenic to 3-day-old chicks, with induction of clinical signs, mortalities, post mortem lesions and adverse effect on the body weight gain. On the other hand, $E$. coli 078 was more pathogenic than $O 11$. The use of the abovementioned drugs for controlling of those infections in chicks was effective as indicated by the results of the in vitro test. It is important to carry out bacteriological examination to the breeder flocks in order to investigate the bacterial affections with estimation of changes in their sensitivity to the used antibiotics.
\end{abstract}

As poultry rearing developed from backyard to be an organized industry, many bacterial pathogens had been incriminated as the cause of ovarian affection of laying hens. These affections including salmonellosis (Elleman, 1960; Sokker et al., 1975; Netherlands, 1990; Al-Nakhal et al., 1999; Shivaprasad, 2000), colibacillosis (Gross and Siegel, 1959; Harry, 1964; Abd El-Nasser, 1976; Azzam, 1983; Ibrahim and Sheha, 1985; Montogomery et al., 1999; Srivasan et al., 2003), and pseudomoniasis (Sharma et al., 1980; Batra et al., 1982; Kheir El-Din et al., 1986; Shehata et al., 1988; Sidu et al., 1989). These bacterial affections resulted in ovarian lesions including misshaped and discolored ovarian follicles, caseated and degenerated ova and egg peritonitis (Saif et al., 2003). Drop in egg production varies according to the nature and type of such infection as $S$. $g$ - $p$ (Shivaprasad, 2000) and E. coli (Bisgaard and

\footnotetext{
* Corresponding author. Tel.: +20 121770699; fax: +2025716840 .

E-mail address: profdramer@yahoo.com (M. M. Amer).
}

Dam, 1981; Gazdziniski and Barnes, 2002) infections can cause $10-30 \%$, while $P$. aeruginosa can cause $20-80 \%$ (Kaul et al., 1992).

Pathogenicity to 1-3-day-old chicks was reported in $S$. $g-p$ (Sieburth and Johanson, 1957; Kosugi et al., 1985; Gorham et al., 1994), E. coli (Awaad, 1972; Khalid, 1990; Andreatti et al., 1993; Johnson et al., 2001) and P. aeruginosa (Ray and Baujeri, 1969; Kheir El-Din et al., 1986; Hamouda et al., 1987).

Antibiogram is recommended for detection of suitable drugs for controlling of such pathogens (Saif et al., 2003) as they acquired drug resistance by pervious, long and hazard one use of these antibacterial drugs.

Infection of chickens with Mycoplasma gallisepticum and Mycoplasma synoviae increase susceptibility to pathogenic and potentially pathogenic organisms like E. coli (Gross, 1990; Nakamura et al., 1994).

This work was carried out to investigate the possible bacterial causes of ovarian lesions in broiler and layer breeder flocks, the antiobiogram of the isolated bacterial strains, the pathogenicity 
of the strains to 3-day-old chicks and the treatment of experimentally infected birds as recommended with the results of the in vitro sensitivity test.

\section{Material and Methods}

Chickens history. Two broiler breeder flocks aged 35 and 56 weeks with total number of 30,500 and 29,300 birds, respectively and one layer breeder flock aged 35 weeks with total number of 22,800 birds showed lower egg production than the farm standard by $8 \%, 12 \%$ and $21 \%$ respectively. The hatchery parameters including fertility and hatchability were also reduced.

\section{Samples.}

1. Ovaries. Thirty ovaries (10/flock) with misshapen, discolored and long stalk caseated cystic ovules were aseptically collected for bacteriological examination.

2. Blood samples. From each flock, 100 blood samples were randomly collected from the wing vein and the sera were separated to be tested using slide agglutination test to confirm the results of the farm test.

Bacteriological examination. Aseptically collected ovaries were subjected to individual testing. One $\mathrm{ml}$ of the follicular content was aspired by a sterile syringe, inoculated into selenite $\mathrm{F}$ broth and incubated at $42^{\circ} \mathrm{C}$ for $18 \mathrm{~h}$ for Salmonella spp. isolation, another $1 \mathrm{ml}$. was inoculated in nutrient broth and incubated at $37^{\circ} \mathrm{C}$ for $24 \mathrm{~h}$. Each of the inoculated broth medium was sub-cultured onto selective agar medium $[5 \%$ sheep blood, Salmonella Shigella (SS), MacConkey, nutrient and pseudomonas agar) plates, then incubated at $37^{\circ} \mathrm{C}$ for $48 \mathrm{~h}$. All the plates were examined for bacterial growth according to (Cruickshank et al., 1975).

Bacterial identification. The obtained bacterial growth was purified, examined for colonial morphology, staining characters (Cruickshank et al., 1975) and subjected to biochemical identification (Edwards and Ewing, 1972; MaCffaddin, 1980; Quinn et al., 1994).

Serological typing. The obtained E. coli and Salmonella spp. strains were serotyped using slide agglutination test against polyvalent and monovalent standard serum obtained from Behring Werk Institute, Germany, using methods of (Neville and Brgant, 1986; Lee and Arp,1998).

Antibiogram. All the isolated strains were tested for their in vitro sensitivity to the following chemotherapeutic discs: neomycin $(30 \mu \mathrm{g})$, oxytetracycline $(30 \mu \mathrm{g})$, trimethoprim $(25 \mu \mathrm{g})$, streptomycin $(10 \mu \mathrm{g})$, ampicillin $(25 \mu \mathrm{g})$, nalidixic acid $(30 \mu \mathrm{g})$, colistin $(10 \mu \mathrm{g})$ and enrofloxacin $(10 \mu \mathrm{g})$ adopting method of Cruickshank et al., (1975) and the results were interpreted according to (Bio-Merieux,1980).

Broth culture. Twenty-four $\mathrm{h}$ broth cultures from S. $g-p, E$. coli $\mathrm{O} 11$ and $\mathrm{O} 78$ as well as $P$. aeruginosa were separately prepared and subjected to plate counting as described (Collins and Lynn's 1989).

Mycoplasmas and S.g-p antigens. Slide agglutination colored antigen against both $M G$ and $M S$ as well as $S . g-p$ were obtained from Intervet Co., Boxmeer, Holland. Serum agglutination tests for Mycoplasma spp. and $S . g-p$. were carried out as stated in NPIP.

Antibiotics used for treatment. According to the results of the in-vitro sensitivity test colistin sulphate $10 \%$ liquid in water (lot No. 1050020) was obtained from Ascor chimici, Forli, Italy and enrofloxacin 10\% (lot No. 604160) from Memphis Co. for Med. Ind., were used for the treatment of experimentally infected chick groups in rate of 6 $\mathrm{mg} / \mathrm{kg}$ for colistin and $10 \mathrm{mg} / \mathrm{kg}$ of enrofloxacin in drinking water for 6 days each.

Experimental chicks. Three hundred and twenty two, day-old male LCL chicks were obtained from commercial hatchery. Ten chicks were sacrificed and bacteriologically examined for freedom of any bacterial pathogen. The remaining chicks were floor reared and fed on commercial ration without antimicrobial feed additives and water was given ad libitum.

Experimental infection. The used three-day-old chicks were orally infected each with $0.2 \mathrm{ml}$ containing $4 \times 10^{4} \mathrm{CFU} /$ bird for $S$. $g-p$ (El-Kady, 1986), $3 \times 10^{7} \mathrm{CFU} /$ bird for $E$. coli (Awaad, 1972) and $3 \times 10^{9} \mathrm{CFU} /$ bird (Kheir El- Din, 1986) for $P$. aeruginosa.

Statistical analysis. The obtained results were statistically analyzed using ANOVA test (Snedecor and Corchran, 1980).

Experimental design. At the $3^{\text {rd }}$ day of life, the remaining 312 chicks were randomly divided into 13 equal groups (1-13), 24 chicks per group. Chick groups were treated as follows: groups 1-3, 4-6, 79 and 10-12 were orally infected with $S . g-p, E$. coli $\mathrm{O} 11, E$. coli $\mathrm{O} 78$ and $P$. aeruginosa, respectively, while chicks of group 13 were kept as non-infected negative control. The infected chicks 
were observed daily for clinical signs and/or mortalities. At the first detection of clinical signs (5-days of age), birds of groups 1, 4, 7 and 10 were treated with colistin, while those of groups 2, 5, 8 and 11 were treated with enrofloxacin. The medicaments were given in the drinking water for 6 days. Birds of groups 3, 6, 9 and 12 were left as infected non-treated controls. All the groups were daily observed for 10 days with recording clinical signs, mortality rates and post-mortem P.M lesions. Bacterial reisolation was tried from dead birds. At the $10^{\text {th }}$ day post-infections ( 3 days after stop medication), 10 randomly selected chicks/group were weighed, sacrificed and examined for (P.M) lesions. Samples from liver, spleen and lung were collected from dead and sacrificed birds and subjected to bacterial reisolation.

\section{Results}

Results of slide agglutination test revealed that the tested sera were positive to M. gallisepticum, M. synoviae and $S$. $g-p$ in rates of $44.35 \%, 63 \%$ and $0 \%$; respectively.

The bacteriological examination of ovaries with lesions showed isolation of 12 bacterial isolates. The obtained isolates were morphologically, staining and biochemically identified to be (5) E. coli, (3) Staphylococci, (2) Proteus, (1) Pseudomonas and (1) non-motile Salmonella. These isolates were further identified to be (3) un-typed E. coli, (1) was O11 and the other was O78; the (3) Staphylococcal isolates were Staphylococcus aureus, (2) Proteus. Salmonella isolate was $S$. gallinarum pullorum and the last one was P.aeruginosa. Identified strains of $E$. coli, $S . g-p$ and $P$. aeruginosa were isolated from the most severe ovarian lesions.

Isolated strains showed variable sensitivity to the available antibiotics when tested in vitro. The tested organisms were totally sensitive to colistin and enrofloxacin, resistant to oxytetracyclin and trimethoprim and variable to the others.

The infected chicks showed signs of illness at the $2^{\text {nd }}$ day post oral infection with rates of $1 / 24$ (4.16\%) for each E. coli $\mathrm{O} 11$ and $S$. $g$-p infected groups, while it was $2 / 24(8.33 \%)$ E. coli $\mathrm{O} 78$ infected group (Table 1). The most predominant signs were off food and ruffled feather. One chick was found dead in $S$. $g-p$ group at the $2^{\text {nd }}$ day postinfection. At the $3^{\text {rd }}$ day of infection, the signs progressed to be $4,2,2$ and $2(16.66 \%, 8.33 \%$,
$8.33 \%$ and $8.33 \%$ ) for E. coli $\mathrm{O} 11$, E. coli $\mathrm{O} 78$, $S . g-p$ and $P$. aeruginosa infected groups respectively, while the mortality was 2, 2, 2 and 1 $(8.32 \%, 8.32 \%, 8.32 \%$ and $4.16 \%)$ for E.coli O11, E.coli O78, S. g- $p$ and P. aeruginosa respectively (Table 1 ).

The detected signs were diarrhea, pasty vent, off food and huddling together for E. coli $\mathrm{O} 11$ and $S . g-p$ infected groups, while the signs were more severe in E. coli O78 group. Group infected with $P$. aeruginosa showed ataxia, incoordination, off food and diarrhea.

All dead birds revealed lesions of septicaemia and enteritis except for E. coli O78 dead chicks showed slight airsaculitis.

At the end of the $10^{\text {th }}$ day post-infection, the total morbidity rates were $62.5 \%, 95.83 \%, 91.66 \%$ and $79.16 \%$ (Table 1, Fig. 1) and the mortality rates reached $20.83 \%, 45.83 \%, 58.53 \%$ and $50 \%$ in groups infected with E. coli O11, E. coli O78, S. $g-p$ and $P$. aeruginosa respectively. The control non-infected group showed no signs or mortality (Table 1, Fig. 2). Dead birds proved positive results for bacterial reisolation.

Non-treated infected groups showed higher morbidity and mortality rates (Table 1 ) than those treated either with colistin or with enrofloxacin (Table 2, Fig. 1, 2).

Results of the mean body weight at the end of observation showed that the infected recovered groups stunted than the non-infected control negative group (Table 3, Fig. 3). The recorded mean weights were the highest $71.32 \mathrm{gm}$ for control, followed by $61.41,58.16,56,36$ and $51.83 \mathrm{gm}$ in descending manner for groups $5,3,2$ and 4 respectively.

Results of body weight in infected non-treated groups (Table 3, Fig. 3) proved significant difference between non-infected group and infected groups 2,3 , and 4 at $\mathrm{P}>0.05$, While the treated groups (Table 4, Fig. 3) proved significant difference in the mean body weight only between group 2 (73.54) and groups 4 (54.80) and 5 (54.63) at $\mathrm{P}>0.05$.

Groups received colistin or enrofloxacin in drinking water at the $3^{\text {rd }}$ day post-infection showed the following results (Table 2, Fig. 1, 2): Clinical signs began to subside at the $5^{\text {th }}$ day post-treatment in all treated groups except those of group 2 and 9, while signs were completely disappeared in all groups at the $6^{\text {th }}$ day. Total mortality rates in each 
Table (1): Distribution of morbidity and mortality rates of 3-day-old infected chicks $(n=24)$.

\begin{tabular}{|c|c|c|c|c|c|c|c|c|c|c|c|c|c|c|}
\hline \multirow{2}{*}{$\begin{array}{c}\text { Group } \\
\text { No. }\end{array}$} & \multirow{2}{*}{ Infection } & \multirow{2}{*}{ Parameters } & \multicolumn{10}{|c|}{ Days post-infection } & \multirow{2}{*}{$\begin{array}{c}\text { Cumulative } \\
\text { positive }\end{array}$} & \multirow{2}{*}{ Positive \% } \\
\hline & & & 1 & 2 & 3 & 4 & 5 & 6 & 7 & 8 & 9 & 10 & & \\
\hline \multirow{2}{*}{1} & \multirow{2}{*}{ Negative } & $\mathbf{S}$ & 0 & 0 & 0 & 0 & 0 & 0 & 0 & 0 & 0 & 0 & 0 & 0 \\
\hline & & $\mathbf{M}$ & 0 & 0 & 0 & 0 & 0 & 0 & 0 & 0 & 0 & 0 & 0 & 0 \\
\hline \multirow{2}{*}{2} & \multirow{2}{*}{ E. coli 011} & $\mathbf{S}$ & 0 & 1 & 4 & 5 & 3 & 2 & 0 & 0 & 0 & 0 & 15 & 62.50 \\
\hline & & M & 0 & 0 & 2 & 0 & 2 & 1 & 0 & 0 & 0 & 0 & 5 & 20.83 \\
\hline \multirow{2}{*}{3} & \multirow{2}{*}{ E. coli 078} & $\mathbf{S}$ & 0 & 2 & 2 & 3 & 5 & 3 & 4 & 4 & 0 & 0 & 23 & 95.83 \\
\hline & & $\mathbf{M}$ & 0 & 0 & 2 & 1 & 2 & 0 & 3 & 1 & 2 & 0 & 11 & 45.83 \\
\hline \multirow{2}{*}{4} & \multirow{2}{*}{ S.g-p } & $\mathbf{S}$ & 0 & 1 & 2 & 2 & 2 & 2 & 4 & 4 & 5 & 0 & 22 & 91.66 \\
\hline & & $\mathbf{M}$ & 0 & 1 & 2 & 1 & 5 & 1 & 3 & 1 & 0 & 0 & 14 & 58.53 \\
\hline \multirow[b]{2}{*}{5} & $\boldsymbol{P}$ & $\mathbf{S}$ & 0 & 0 & 2 & 2 & 2 & 3 & 3 & 3 & 4 & 0 & 19 & 79.16 \\
\hline & aeruginosa & $\mathbf{M}$ & 0 & 0 & 1 & 1 & 3 & 3 & 2 & 1 & 1 & 0 & 12 & 50.00 \\
\hline
\end{tabular}

S: Number of birds with signs.

M: Number of dead birds.

S. g-p: Salmonella gallinarum pullorum.

Table (2): Distribution of morbidity and mortality rates in 5-day-old infected and treated chicks $(\mathrm{n}=\mathbf{2 4})$.

\begin{tabular}{|c|c|c|c|c|c|c|c|c|c|c|c|}
\hline \multirow{2}{*}{$\begin{array}{c}\text { Group } \\
\text { No. }\end{array}$} & \multirow[b]{2}{*}{ Infection } & \multirow[b]{2}{*}{ Treatment } & \multirow[b]{2}{*}{ Parameters } & \multicolumn{6}{|c|}{ Days post-treatment } & \multirow{2}{*}{$\begin{array}{l}\text { No. of } \\
\text { positive }\end{array}$} & \multirow{2}{*}{$\begin{array}{c}\% \text { of } \\
\text { positive }\end{array}$} \\
\hline & & & & 1 & 2 & 3 & 4 & 5 & $6-7$ & & \\
\hline \multirow{2}{*}{1} & \multirow{2}{*}{ Negative } & \multirow{2}{*}{ Negative } & $\mathbf{S}$ & 0 & 0 & 0 & 0 & 0 & 0 & 0 & 0 \\
\hline & & & $\mathbf{M}$ & 0 & 0 & 0 & 0 & 0 & 0 & 0 & 0 \\
\hline \multirow[b]{2}{*}{2} & \multirow{4}{*}{ E. coli 011} & \multirow{2}{*}{ Colistin } & $\mathbf{S}$ & 4 & 5 & 3 & 2 & 1 & 0 & 15 & 62.50 \\
\hline & & & $\mathbf{M}$ & 1 & 2 & 0 & 1 & 0 & 0 & 4 & 16.67 \\
\hline \multirow{2}{*}{3} & & \multirow{2}{*}{ Enrofloxacin } & $\mathbf{S}$ & 1 & 4 & 5 & 2 & 0 & 0 & 12 & 50.00 \\
\hline & & & $\mathbf{M}$ & 2 & 3 & 1 & 0 & 0 & 0 & 6 & 25.00 \\
\hline \multirow{2}{*}{4} & \multirow{4}{*}{ E. coli $O 78$} & \multirow{2}{*}{ Colistin } & $\mathbf{S}$ & 1 & 3 & 3 & 2 & 0 & 0 & 9 & 37.50 \\
\hline & & & $\mathbf{M}$ & 2 & 2 & 1 & 0 & 0 & 0 & 5 & 20.83 \\
\hline \multirow{2}{*}{5} & & \multirow{2}{*}{ Enrofloxacin } & $\mathbf{S}$ & 3 & 2 & 2 & 1 & 0 & 0 & 8 & 33.33 \\
\hline & & & $\mathbf{M}$ & 1 & 0 & 1 & 1 & 0 & 0 & 3 & 12.50 \\
\hline \multirow[b]{2}{*}{6} & \multirow{4}{*}{ S. g-p } & \multirow{2}{*}{ Colistin } & $\mathbf{S}$ & 3 & 3 & 2 & 1 & 0 & 0 & 9 & 37.50 \\
\hline & & & $\mathbf{M}$ & 2 & 2 & 0 & 0 & 0 & 0 & 4 & 16.67 \\
\hline \multirow{2}{*}{7} & & \multirow{2}{*}{ Enrofloxacin } & $\mathbf{S}$ & 3 & 4 & 2 & 1 & 0 & 0 & 10 & 41.67 \\
\hline & & & $\mathbf{M}$ & 2 & 1 & 1 & 0 & 0 & 0 & 4 & 16.67 \\
\hline \multirow[t]{3}{*}{8} & \multirow{4}{*}{$P$. aeruginosa } & \multirow{2}{*}{ Colistin } & $\mathbf{S}$ & 3 & 3 & 4 & 1 & 0 & 0 & 11 & 45.83 \\
\hline & & & $\mathbf{M}$ & 2 & 1 & 2 & 1 & 0 & 0 & 6 & 25.00 \\
\hline & & \multirow[b]{2}{*}{ Enrofloxacin } & $\mathbf{S}$ & 3 & 3 & 2 & 0 & 1 & 0 & 9 & 37.50 \\
\hline 9 & & & $\mathbf{M}$ & 1 & 2 & 2 & 0 & 0 & 0 & 5 & 20.83 \\
\hline
\end{tabular}

S: Number of birds with signs.

M: Number of dead birds.

S. $g$ - $p$ : Salmonella gallinarum pullorum. 
Table (3): Mean body weight of infected non-treated chicks (n=10).

\begin{tabular}{ccccc}
\hline \multirow{2}{*}{ Group No. } & \multirow{2}{*}{ Infection } & \multicolumn{3}{c}{ Body weight/gm } \\
\cline { 3 - 5 } & & Minimum & Maximum & Mean \pm SD \\
\cline { 3 - 5 } $\mathbf{1}$ & Negative & 44.4 & 95.92 & $71.32^{*} \pm 16.27$ \\
$\mathbf{2}$ & $\boldsymbol{E}$. coli $\boldsymbol{O} 11$ & 46.8 & 64.85 & $56.36^{*} \pm 5.58$ \\
$\mathbf{3}$ & $\boldsymbol{E}$.coli $\mathbf{7 8}$ & 44.45 & 67.28 & $58.16^{*} \pm 5.97$ \\
$\mathbf{4}$ & S.g-p & 38.10 & 60.70 & $51.83^{*} \pm 7.19$ \\
$\mathbf{5}$ & P. aeruginosa & 53.00 & 67.57 & $61.41 \pm 4.61$ \\
\hline
\end{tabular}

S.g-p: Salmonella gallinarum pullorum.

*: Significant difference at $\mathrm{p}>0.05$.

Table (4): Mean body weight of infected and treated chicks $(n=10)$.

\begin{tabular}{|c|c|c|c|c|c|}
\hline \multirow{2}{*}{ Group No. } & \multirow{2}{*}{ Infection } & \multirow{2}{*}{ Treatment } & \multicolumn{3}{|c|}{ Body weight/gm } \\
\hline & & & Minimum & Maximum & Mean \pm SD \\
\hline 1 & Negative & Negative & 44.4 & 95.92 & $71.32 \pm 16.27$ \\
\hline 2 & & Colistin & 45.70 & 92.75 & $73.54 * \pm 13.05$ \\
\hline 3 & E. coll OII & Enrofloxacin & 56.50 & 82.84 & $68.41 \pm 7.57$ \\
\hline 4 & & Colistin & 37.90 & 74.85 & $54.80 * \pm 9.36$ \\
\hline 5 & E. coli 078 & Enrofloxacin & 34.56 & 72.95 & $54.63^{*} \pm 10.37$ \\
\hline 6 & & Colistin & 53.96 & 73.30 & $59.86 \pm 11.69$ \\
\hline 7 & S.g-p & Enrofloxacin & 38.86 & 69.58 & $54.75 \pm 8.54$ \\
\hline 8 & & Colistin & 44.70 & 71.88 & $59.31 \pm 8.19$ \\
\hline 9 & P. aeruginosa & Enrofloxacin & 50.20 & 62.86 & $59.31 \pm 3.66$ \\
\hline
\end{tabular}

S.g-p: Salmonella gallinarum pullorum.

*: Significant difference at $\mathrm{p}>0.05$.

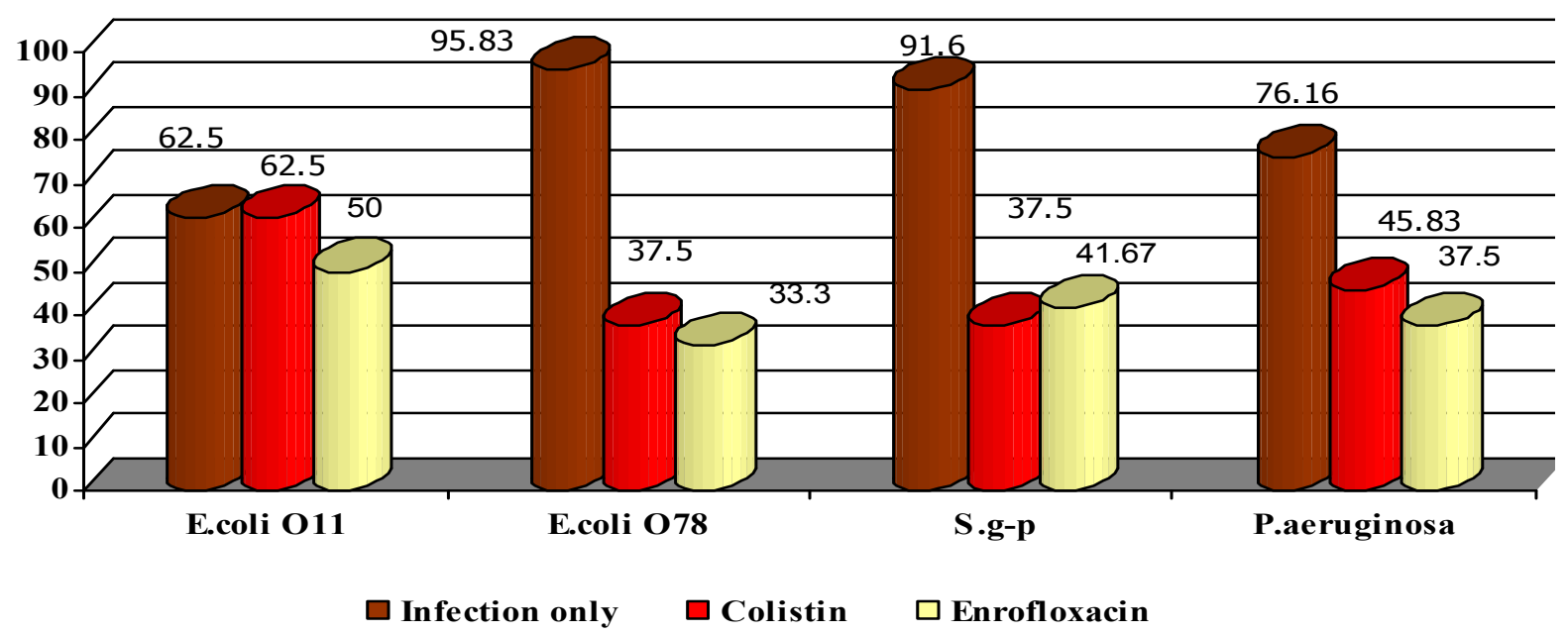

Fig. (1): Morbidity rates in infected-treated groups as compared with infected non-treated control groups. 


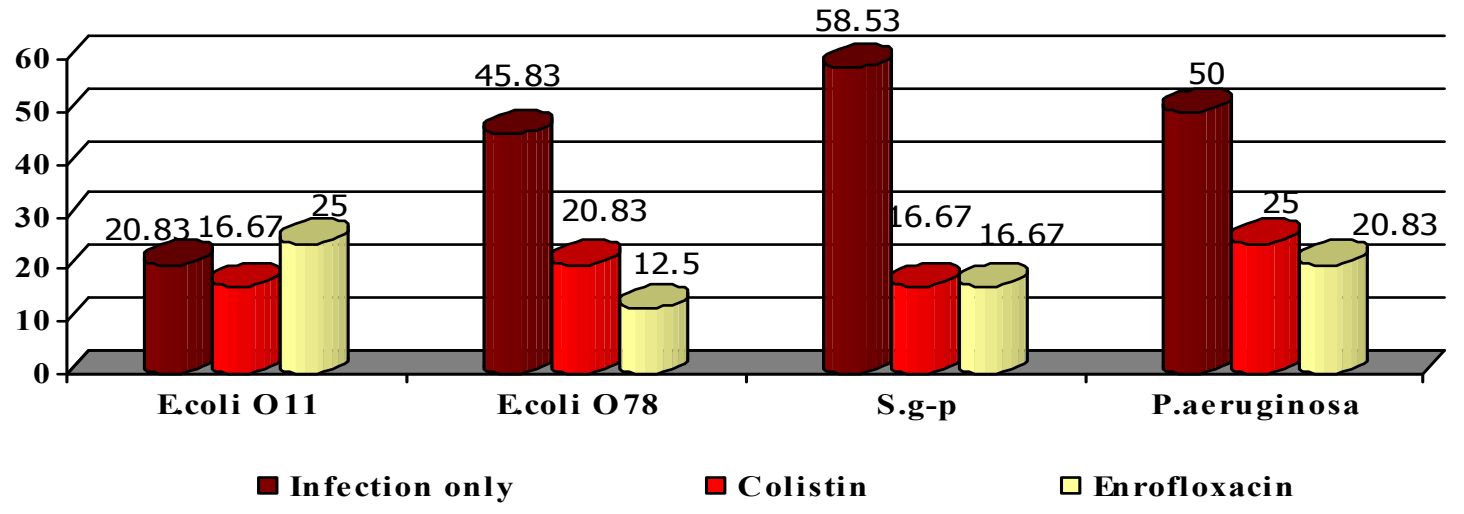

Fig. (2): Mortality rates in infected-treated groups as compared with infected non-treat control groups.

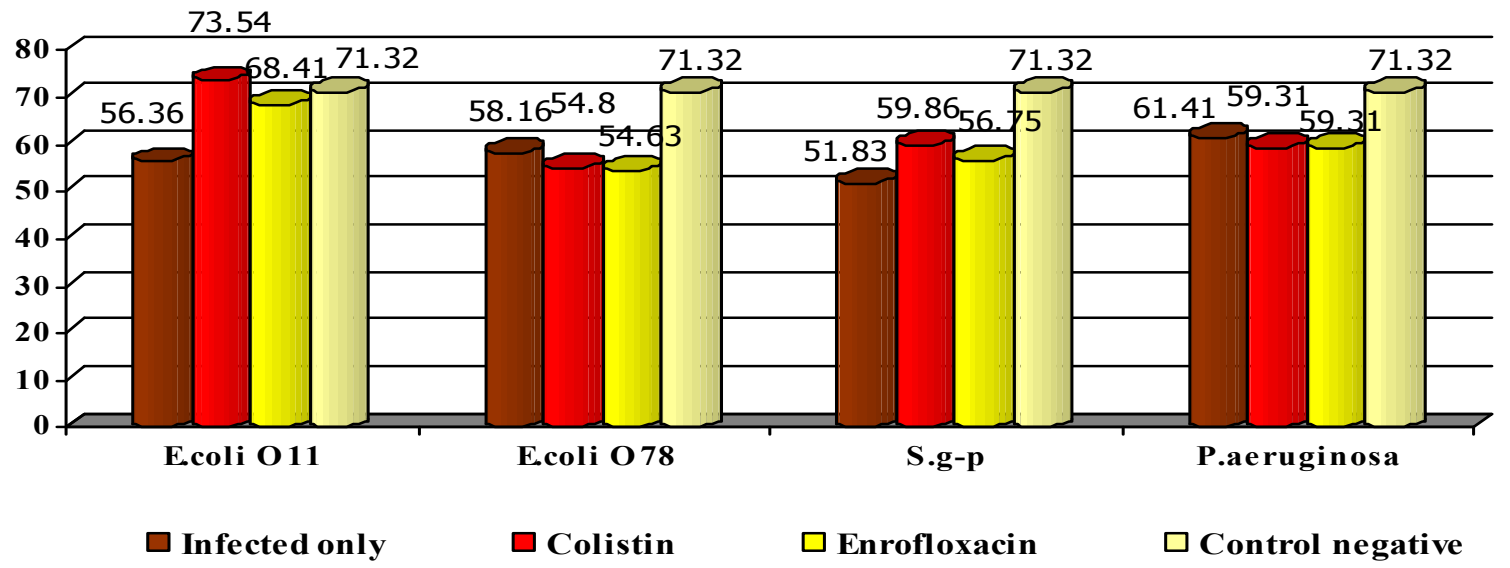

Fig. (3): Mean body weight in infected treated groups as compared with infected non-treated and non-infected control groups.

of group 3 and 8 was (25\%) higher than those of groups 4 and $9(20.83 \%)$ followed by $16.67 \%$ in groups 2, 6 and 7 while group 5 showed the lowest mortality rate $(12.5 \%)$.

\section{Discussion}

Many bacterial infections have economical importance in laying breeder flocks including $E$. coli (Bisgaard and Dam, 1981; Gazdziniski and Barnes, 2002), Salmonella gallinarum pullorum (Shivaprasad, 2000) and P. aeruginosa through their effects on the ovary inducing; pathological lesions, and lowered fertility, hatchability and egg production (Saif et al., 2003).

The positive results of serum plate agglutination test to Mycoplasma spp. indicated that the flocks under test were infected. It was found that $M G$ and $M S$ increased the susceptibility to infection with E.coli as stated by (MacOwan et al., 1982; Gross, 1990; Nakamura et al., 1994; van de Zande et al., 2001). The negative results of serum plate agglutination test to $S . g-p$ can be attributed to that reported by Gast and Beard, (1990) where hens infected with antigenically intermediate or variant strains of S.pullorum were detected as sero-positive less often than hens infected with antigenically standard strains. Therefore, ovaries with lesions could be involved in sampling for isolation as recommended by Shivaprasad (2000).

Results of bacteriological isolation and identification proved the isolation of E.coli as reported (Abd El-Nasser, 1976; Osklokov and Saltykov, 1976; Zahdeh, 1982; Azzam, 1983). Serologically, those isolates were typed to be O11 
(Abd El-Nasser, 1976; Andrawis, 1980); while O78 was also reported (Karmy et al., 1987; Singab, 1987).S.g- $p$ was identified as an ovarian isolate of laying chickens (Saif et al., 2003). On the other hand, P.aeruginosa was detected from ovaries with obvious lesions (Sharma et al., 1980; Batra et al., 1982; Kheir El-Din et al., 1986; Riad, 1994).

The in vitro sensitivity test of the isolated strains gave variable results to the used drug discs. This point was reported (Azzam, 1983; Riad 1994). The most effective antibacterial drugs were colistin and enrofloxacin as detected previously (Riad, 1994), while Abd El-Ghafar (1979) proved resistance of all tested strains to colistin. Abd ElWahab (1977), Welsh et al., (1997) and Salmon and Watts, (2000) reported the sensitivity of the isolates to enrofloxacin.

For studying the pathogenicity of the identified organisms to 3-day-old chicks, oral route was used for the experimental infection with $24 \mathrm{~h}$ broth cultures. E.coli infected birds showed clinical signs and lesions similar to those reported (Abd El-Wahab 1977; Bassiouni et al., 1979; Azzam 1983).

Results of infection with E.coli O11 and O78 and the control non-infected group showed that mortality percentage in groups infected with E.coli O11 was $20.83 \%$, while it was $45.83 \%$ in-group infected with E.coli O78. These results were higher than those of Davis (1938) where as E.coli induced losses ranged from $15-40 \%$ in chicks less than 10-days of age. The detected lesions were similar to those previously reported by Azzam (1983) and Singab (1987) who observed gross lesions including pericarditis and perihepatitis at 37 days post infection; while airsaculitis was also reported (Batra et al., 1982).

Morbidity and mortality rates were higher ingroup received E.coli $\mathrm{O} 78$ than those of group received O11. O78 was reported to be more commonly pathogenic to chickens than O11 (Harry, 1964; Sojka, 1965). Moreover, Bassiouni et al., (1979) concluded that E.coli O78 was highly pathogenic to 3-day-old chicks and it was more pathogenic than O11. Alian (1978) recorded 50\% mortality rate in day-old chicks orally infected with E.coli O78.

The group infected with $S . g-p$ showed signs, lesions, $91.66 \%$ morbidity rate and $58.53 \%$ mortality rate. El-Kady (1986) reported similar signs and lesions in 2-day-old chicks but only with $8.54 \%$ mortality rate.

The recorded signs and lesions in chicks of group infected with P.aeruginosa were similar to those noticed by Hamouda et al., (1987). The recorded mortality rate $(50.0 \%)$ was lower than that of Hamouda et al., (1987) which was 56\% while, Lin et al., (1996) sated that P.aeruginosa could cause $50-100 \%$ mortality rate in experimentally inoculated 4-week-old chickens.

The mean body weight in group infected with $P$.aeruginosa was lower than that of non-infected group. Kheir El-Din et al., (1986), reported similar result.

Colistin and enrofloxacin were used in the treatment as recommended by the results of the in vitro test. Both drugs were effective in reducing morbidity, mortality rates and restoring body weight in the treated groups regardless to the type of the organism as compared with negative and non-treated control.

This study pointed out that E.coli, $s, g-p$ as well as $P$.aeruginosa can cause reduction in the breeder flocks performance, especially when they are serologically positive to Mycoplasma spp. The antibiogram is necessary for controlling such infections.

\section{References}

Abd El-Ghafar, A. M. (1979): The role of R-factor of $E$. coli causing Coli-septicemia and its elimination in poultry. M. V. Sc., Thesis, Fac. Vet. Med., Cairo Univ., Egypt.

Abd El-Nasser, A. H. T. (1976): Bacteriological studies of $E$. coli in chickens in Egypt. M. V. Sc., Thesis, Fac. Vet. Med., Cairo Univ., Egypt.

Abd El-Wahab, Z. (1977): Studies on Colibacillosis in chickens. M. V. Sc., Thesis, Fac. Vet. Med., Cairo Univ., Egypt.

Alian, A. (1978): Studies on Coliseptecimia in Saudi Arabia. M. V. Sc., Thesis, Fac. Vet. Med., Cairo Univ., Egypt.

Al-Nakhal, H. M.; Al-Ogaily, Z. H. and Nassar, T. J. (1999): Representative Salmonella serovars isolated from poultry enviroment in Saudi Arabia. Revue Scientifique et Technique-OIE., 18(3): 700-709.

Andrawis, A. A. (1980): Studies on Enterobacteriacae in poultry. M. V. Sc., Thesis, Fac. Vet. Med., Cairo Univ., Egypt.

Andreatti, R. L.; Silva, E. and Balen, L. (1993): Effect of route of inoculation on the pathogenicities of pathogenic and non pathogenic Escherichia coli strains in chickens. AquivoBiosilerio de Medicina-Vet.-e-Zootecnia., 45 (5): 475-486.

Awaad, M. H. H. (1972): Studies on E. coli infection in chickens. M. V. Sc., Thesis, Fac. Vet. Med., Cairo Univ., Egypt.

Azzam, A. H. (1983): Studies on Colibacillosis in poultry in Dakahlea province. M. V. Sc., Thesis, Fac. Vet. Med., Cairo Univ., Egypt. 
Bassiouni, A. A.; Sheinnawi, M. M.; Hasasanin, Z A.; Youssef, Y. I. and Awaad, M. H. H. (1979): Studies on the role of $\mathrm{K}$ antigen inducing Colisepticaemia in chickens. Zagazig. Vet. J., (2): 23-30.

Batra, G. L.; Balwant, S.; Grewal, G. S. and Sodhi. S. S. (1982): Aetiopathology of oophoritis and salpingitis in domestic fowl. Ind. J. Poult. Sci., 52:172-176.

Bio-Merieux (1980): Laboratory reagents and productsbacteriology. Marley L. Etoile 69260 Charbonnieres, les Bains, France.

Bisgaard, M. and Dam, A. (1981): Salpingitis in poultry. II. Prevalence, bacteriology, and possible pathogenesis in egg laying chickens. Nord. Vet., 33: 81-89.

Collins, C. H. and Lynn's, M. (1989): Microbiological methods. $6^{\text {th }}$ ed., Butterworth's, London.

Cruickshank, R.; Duguid, P.; Marmion, B. D. and Swain, R. H. A. (1975): Medical microbiology. $12^{\text {th }}$ ed.,Vol II, Churchill living-stone, Edinburgh, London and New York.

Davis, C. R. (1938): Colibacillosis in young chicks. J Am. Vet. Med. Assoc., 92:518-522.

Edwards, P. R. and Ewing, W. H. (1972): Identification of Enterobacteriaceae. Burgess. Pupl. Co. Minnecepois, Minnesota.

El-Kady, M. F. (1986): Studies on Salmonella gallinarum pullorum infection in poultry in Beni-Suef. M. V. Sc., Thesis, Fac. Vet. Med., Cairo Univ., Egypt.

Elleman, G. (1960): Examination of fowls at a poultry plant for Salmonella bacteria in the colaca. Nord. Vet. Med., 12:4753 .

Gast, R. K. and Beard. C. W. (1990): Serological detection of experimental Salmonella enteritidis infection in layer hens. Avian Dis., 34:721-728.

Gazdziniski, P. and Barnes. H. J. (2002): Venereal colibacillosis (acute vaginitis) in turkey breeder hens. Proc $51^{\text {st }}$ Western Poult Dis. Conf: Puerto Vallarta, MX, May, 14:176-177.

Gorham, L.; Kodovil, K. and Vaughan, E. (1994): Gross and microscopic lesions in young chickens experimentally infected with $S$. enteritidis. Avian Dis., 38: 816-821.

Gross, W. B. (1990): Factors affecting the development of respiratory disease complex in chickens. Avian Dis., 34: 607610.

Gross, W. B. and Siegel, P.B. (1959): Coliform peritonitis of chickens. Avian Dis., 3: 370-373.

Hamouda, A. S.; Amer, M. M.; Bastami, M. A. and ElKady, M. (1987): Some aspects of P. aeruginosa infection in chickens. Assuit Vet. Med. J.,19:179-184.

Harry, E. G. (1964): The survival of E. coli in the dust of poultry houses. Vet. Rec., 76:466-470.

Ibrahim, A. A. and Sheha, M. A. (1985): Some observations on Colisepticaemia of laying chickens. Assiut. Vet. Med. J.,14: 235-240.

Johnson, L. C.; Bilgili, S. F.; Hoerr, F. J.; Mc Muurtrey, B. L. and Norton, R. A. (2001): The effect of early exposure of cellulites associated E. coli in one day old chickens. Avian Pathol., 30 (20): 175-178.

Kaul, P. L.; Kaul, L.; Patel, B. J. and Shah, N.H. (1992): Incidence of $P$. aeruginosa in layers. Ind. Vet. J., 69 (10): 948-949.

Karmy, S.; Shauman, M. T.; Ragab, A. M.; Safwat, E.E. A. and El-Danaf, N. (1987): Studies on the efficiency and level of flumequine in healthy and experimentally infected birds with E. coli O78:K80 in vitro and vivo. J. Egypt. Vet. Med. Assoc., 47: 521-536.

Khalid, M. (1990): Studies on natural and experimental E.coli infection in chicken. J. Egypt. Vet. Med. Assoc., 50 (3): 379-389.

Kheir El-Din, A.; Hatem, E. and Shouman, M.T. (1986): Experimental investigation on avian Pseudomonus aeruginosa in Egypt. Vet Med. J., 34 (11):125-134.

Kosugi, Y.; Cheng, M. C.; Hung, K. J. and Isai, W. C. (1985): Effect of cage contamination with coccidia and salmonella on acute salmonellosis in young chickens. Avian Dis., 30 (2): 313-317.

Lee, M. D. and Arp. L. H. (1998): Colibacillosis. In D. E. Swayne, J. R. Glisson, M. W. Jackwood, J. E. Pearson, and W. M. Reed (eds.). A Laboratory Manual for the Isolation and Identification of Avian Pathogens. Am. Assoc. Avian Pathologists: Kennett Square, PA, 14-16.

Lin, J. A.; Shyu, C. and Shyu. C. L. (1996): Detection of gram-negative bacterial flora from dead-in-shell chicken embryo, non-hatched eggs, and newly hatched chicks. J Chinese Soc. Vet. Sci., 22: 361-366.

MaCffaddin, J. E. (1980): Biochemical tests for identification of medical bacteria, $2^{\text {nd }}$ ed.,Williams and Wilkins Co., Baltimore, USA.

MacOwan, K. J.; Randall, C. J; Jones, H. G. R. and Brand. T. F. (1982): Association of Mycoplasma synoviae with respiratory disease of broilers. Avian Pathol., 11: 235244.

Montogomery, R. D.; Boyle, C. R.; Lenarduzzi, T. A. and Jones, L. S. (1999): Consequences to chicks hatched from Escherichia coli-inoculated embryos. Avian Dis., 43:553-563.

Nakamura, K.; Ueda, H.; Tanimura, T. and Noguchi, K. (1994): Effect of mixed live vaccine (Newcastle disease and infectious bronchitis) and Mycoplasma gallisepticum on the chicken respiratory tract and on Escherichia coli infection. J. Comp. Pathol., 111:33-42.

Netherlands, N. (1990): Salmonella survey, particularly for $S$. enteritidis among Dutch poultry farms. Tijdschrift voor diergenees kunde., 115 (21):1005-1008.

Neville, J. and Brgant, A. F. (1986): Laboratory and serology. $2^{\text {nd }}$ ed., Saunder Co., Toronto, Canada.

NPIP: The National Poultry Improvement Plan and Auxiliary Provisions. United States Department of Agriculture, Animal and Plant Health Inspection Service: Hyattsville, MD.

Osklokov, U. S. and Saltykov, A. K. (1976): Properties of $E$. coli strains from diseased fowls. Vet. Moscow, RSSR., 10: 66-68.

Quinn, P. J.; Cartewr, M.E.; Markry, B.T. and Carter, G. R. (1994): Clinical veterinary microbiology, Wolf, London, New York.pp. 237-242.

Ray, S. and Baujeri, T. P. (1969): Pseudomonas pyoganea septicaemia in young chicks. Ind. Vet. J., 46: 547-551.

Riad, E. M. (1994): Characterization of Pseudomonas species isolated from domestic animals and poultry. Ph. D., Thesis, Fac. Vet. Med., Cairo Univ., Egypt.

Saif, Y. M. ; Barnes, H. J.; Fadly, A. M. ; Glisson, J. R. ; McDougald, L. R. and Swayne D. E. ( 2003): Diseases of Poultry, $11^{\text {th }}$ ed., Iowa State Press, A Blackwell Publishing Co.

Salmon, S. A. and Watts. J. L. (2000): Minimum inhibitory concentration determinations for various antimicrobial agents against 1570 bacterial isolates from turkey poults. Avian Dis., 
44:85-98.

Sharma, J. K.; Joshi, D. V and Baxi. K. K. (1980): Studies on the bacteriological etiology of reproductive disorders of poultry. Ind. J. Poult. Sci., 15:78-82.

Shehata , M. A. ; El-Timawy, A. M. and Seddik, I. (1988): Occurrence of Pseudomonas infections in fowl in upper Egypt. Assuit. Vet. Med. J., 20:168-177.

Shivaprasad, H. L. (2000): Fowl Typhoid and Pullorum disease. Rev. Sci. Tech. of Int Epiz., 19: 405-424.

Sidu, B. S.; Sandhu, K. S. and Kumar, N. (1989): Bacterial etiology of decreased egg production in poultry. Ind. J. Comp. Microbiol. Immunol. Inf. Dis., 10 (1) 39-42.

Sieburth, J. M. and Johanson, E. P. (1957): Observation on stress factors and serological response in S. typhimurium infection in chicks. Proc. $18^{\text {th }}$ Ann. Conf. Lab. Workers on pullorum.

Singab, F. A. (1987): Studies on respiratory disease complex in chickens with special reference to bacterial aspect. M. V. Sc., Thesis, Fac. Vet. Med., Cairo Univ., Egypt.

Snedecor. G. W. and Corchran, W. G. (1980): Statistical
Methods. Iowa State University Press, Ames, IA.

Sojka, W. J. (1965): Escherichia coli in Domestic Animals and Poultry. Commonwealth Agricultural Bureau: Farnham Royal, England.

Sokker, H. M.; Abass, K. and Abd El-Malek. A. (1975): Investigation of an outbreak of acute $S$. gallinarum pullorum in adult chickens. Assuit. Vet. Med. J., 11:227-231.

Srivasan, P.; Rao, G. V. S. and George, V. I. (2003): Survey of spontaneous cases of colibacillosis in chickens. Ind. Vet. J., 80 (1): 93-94.

Van de Zande, S. ; Nauwynck, H. and Pensaert. M. (2001): The clinical, pathological and microbiological outcome of an Escherichia coli $\mathrm{O} 2: \mathrm{K} 1$ infection in avian pneumovirus infected turkeys. Vet. Microbiol., 81:353-365.

Welsh, R. D.; Nieman, R. W.; Vanhooser, S. L. and Dye. L. B. (1997): Bacterial infections in ratites. Vet. Med., 92: 992-998.

Zahdeh, A. H. (1982): Studies on problem of omphalitis in chickens. M. V. Sc., Thesis, Fac. Vet. Med., Cairo Univ., Egypt.

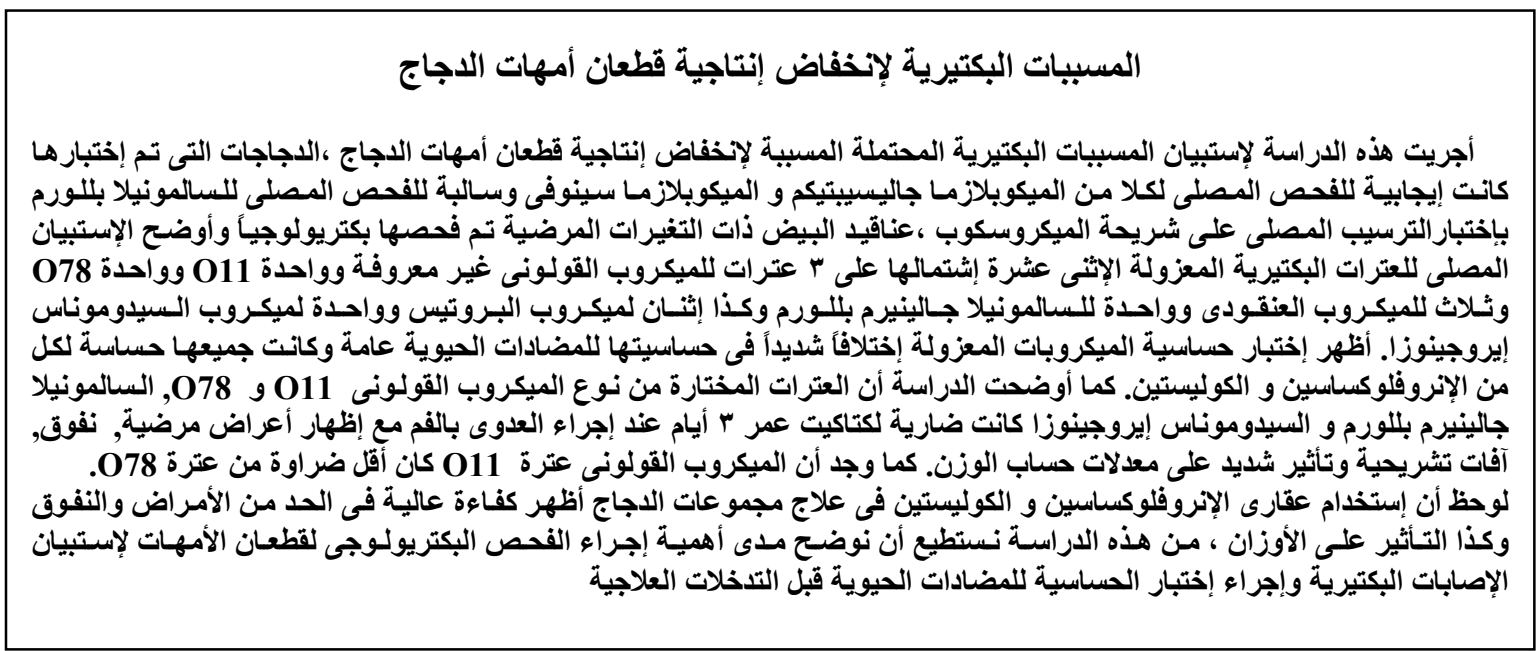

